\title{
Polistes versicolor (Hymenoptera: Vespidae), an Introduced Wasp in the Galapagos Islands: Its Life Cycle and Ecological Impact
}

\author{
Christine E. Parent, ${ }^{1}$ Stewart B. Peck, ${ }^{2}$ Charlotte E. Causton, ${ }^{3, \bullet}$ Lázaro Roque-Albelo, ${ }^{3}$ \\ Philip J. Lester, ${ }^{4, \bullet}$ and Mariana Bulgarella ${ }^{4,5, \bullet}$
}

${ }^{1}$ Department of Biological Sciences and Institute for Bioinformatics and Evolutionary Studies, University of Idaho, 875 Perimeter MS 3051, Moscow 83844, ID, ${ }^{2}$ Department of Entomology, Research and Collections Division, Canadian Museum of Nature, P.0. Box 3443, Station D, Ottawa ON K1P 6P4, Canada, ${ }^{3}$ Charles Darwin Research Station, Charles Darwin Foundation, Puerto Ayora, Santa Cruz Island, Galápagos Islands, Ecuador, ${ }^{4}$ School of Biological Sciences, Victoria University of Wellington, P.0. Box 600, Wellington 6140, New Zealand, and ${ }^{5}$ Corresponding author, e-mail: mariana.bulgarella@vuw.ac.nz

Subject Editor: Darrell Ross

Received 26 May 2020; Editorial decision 11 August 2020

\begin{abstract}
The yellow paper wasp, Polistes versicolor (Olivier) was first recorded in the Galapagos archipelago in 1988. Its life cycle and ecological impacts were studied on two islands $11 \mathrm{yr}$ after it was first discovered. This invasive wasp adapted quickly and was found in most environments. Colony counts and adult wasp monitoring showed a strong preference for drier habitats. Nest activities were seasonally synchronized, nest building followed the rains in the hot season (typically January-May), when insect prey increases, and peaked as temperature and rains started to decline. Next, the number of adult wasps peaked during the cool season when there is barely any rain in the drier zones. In Galapagos, almost half of the prey loads of $P$. versicolor were lepidopteran larvae, but wasps also carried spiders, beetles, and flies back to the colonies. An estimated average of $329 \mathrm{mg}$ of fresh insect prey was consumed per day for an average colony of 120-150 wasp larvae. The wasps preyed upon native and introduced insects, but likely also affect insectivorous vertebrates as competitors for food. Wasps may also compete with native pollinators as they regularly visited flowers to collect nectar, and have been recorded visiting at least 93 plant species in Galapagos, including 66 endemic and native plants. Colonies were attacked by a predatory moth, Taygete sphecophila (Meyrick) (Lepidoptera: Autostichidae), but colony development was not arrested. High wasp numbers also affect the activities of residents and tourists. A management program for this invasive species in the archipelago is essential.
\end{abstract}

\section{Resumen}

La avispa de papel amarilla, Polistes versicolor (Olivier) se registró por primera vez en el archipiélago de Galápagos en 1988. Estudiamos su ciclo de vida e impacto ecológico en dos islas once años después de que fue descubierta. Esta avispa invasora se adaptó fácilmente a las islas y se encuentra en la mayoría de los hábitats. Los conteos de colonias y el monitoreo de avispas adultas sugieren una fuerte preferencia por los hábitats más secos. Las actividades de las colonias están temporalmente sincronizadas; la construcción de nidos comienza luego de las primeras lluvias en la estación cálida (típicamente de enero a mayo), cuando aumenta la abundancia de insectos, con el máximo número de colonias registrado cuando la temperatura y las lluvias comenzaron a disminuir, seguido por un aumento del número de avispas adultas en la estación fría, cuando prácticamente no llueve en las zonas más secas. En Galápagos, casi la mitad de las presas capturadas por $P$. versicolor fueron larvas de Lepidoptera, pero las avispas también llevaron arañas, escarabajos y moscas a sus colonias. Una colonia promedio de entre 120 a 150 larvas de avispas consume un promedio estimado de 329 mg de presas frescas por día. Las avispas depredan insectos nativos e introducidos, pero también es probable que afecten a los vertebrados insectívoros compitiendo por comida. Estas avispas también podrían estar compitiendo con polinizadores nativos ya que visitan flores regularmente para colectar néctar y han sido registradas visitando por lo menos 93 especies de plantas en Galápagos, incluyendo 66 plantas endémicas y nativas. Las colonias fueron atacadas por una polilla depredadora, Taygete sphecophila (Meyrick) (Lepidoptera: Autostichidae), pero la infestación no afectó el ciclo de las colonias. Un 
gran número de avispas también impacta las actividades de residentes y turistas. Es esencial que se desarrolle un programa de manejo de esta especie invasora en el archipiélago.

Key words: invasive insects, island invasion, paper wasps, predation

Biodiversity loss on oceanic islands is mainly driven by biological invasions (Bellard et al. 2017), and is of particular concern because these islands harbor a high proportion of endemic and specialized plant and animal species (Whittaker and Fernández-Palacios 2007). Island ecosystems are more vulnerable to invasions than continental ecosystems because they are less saturated, native species are often defenseless against novel predators and competitors, and have small populations (Simberloff 2000).

The Galapagos Islands, a World Heritage Site, are a province of Ecuador. They are located $960 \mathrm{~km}$ off the west coast of South America and lie on the equator. Their oceanic isolation, recent geological origin, and climatic diversity have promoted biotic speciation (Parent et al. 2008, Gillespie and Roderick 2014). The total insect fauna inhabiting the Galapagos Islands presents a relatively high level of endemism of an average of 56\% (Gosliner 2009). In addition, some insect orders show even higher levels of endemism; for example, $67 \%$ of the beetle species found in Galapagos do not occur anywhere else in the world (Peck et al. 1998). With the arrival of humans to the Galapagos Islands, as early as 1535 A.D., some insect species that could not possibly have reached the islands by themselves were accidentally introduced, and humans have since continuously contributed to the arrival and spread of introduced insects (Causton et al. 2006, Toral-Granda et al. 2017). The rate of accumulation of introduced insect species closely parallels the in crease in both the population of human residents and the number of tourist visitors per year (Peck et al. 1998, Toral-Granda et al. 2017). At least 545 species of insects have been accidentally introduced to the islands by human activity (Toral-Granda et al. 2017). Species that have been identified as highly invasive include the tramp ants (Wasmannia auropunctata (Roger), Solenopsis geminata Fabricius, Pheidole megacephala (Fabricius), and Monomorium destructor (Jerdon)) (Hymenoptera: Formicidae), a bird-parasitic fly (Philornis downsi) Dodge \& Aitken (Diptera: Muscidae), and two vespid wasps (Brachygastra lecheguana (Latreille) and Polistes versicolor (Olivier)) (Hymenoptera: Vespidae) (Causton and Sevilla 2007, CDF and WWF 2018).

Polistes versicolor was first recorded in Galapagos on the island of Floreana in 1988 (Abedrabbo 1991). A colony or colonies are suspected to have arrived on some human-made structure on board a cargo ship (Landry et al. 2006). Since then, these wasps have spread to almost all islands of the archipelago (Causton et al. 2006). Polistes wasps are likely to impact ecosystems in various ways. They are known to be voracious predators of insect larvae (Prezoto et al. 2006, Elisei et al. 2010) and are likely to compete for this food resource with other insectivorous vertebrate species found in the Galapagos Islands such as Darwin's finches, geckos, and lava lizards (Supp Table 1 [online only]; Heraty and Abedrabbo 1992). They are also known to visit flowers (Grant and Grant 1997, McMullen 1999) and could compete with native species for floral resources.

Our study focuses on the population dynamics of this invasive species shortly after colonizing the Galapagos Islands. Our objectives in this study were: 1 ) to describe $P$. versicolor colony numbers and distribution on two high-elevation, inhabited islands of the Galapagos archipelago: Santa Cruz and Floreana islands; 2) gain information on the population dynamics of $P$. versicolor in relation to habitat and climate preferences; 3 ) understand the foraging behavior and identify the prey items hunted by $P$. versicolor; 4) gain insight into the biotic interactions between $P$. versicolor and the flora and fauna to understand the impacts posed by this introduced vespid. These data will provide a baseline for an ongoing study to develop methods to manage this invasive species in Galapagos ecosystems.

\section{Materials and Methods}

\section{Study Sites}

Fieldwork to study colony numbers, distribution, dynamics, and wasp foraging habits was conducted on Santa Cruz Island $\left(0.742806^{\circ} \mathrm{S}\right.$, $\left.90.302889^{\circ} \mathrm{W}\right)$ and Floreana Island $\left(1.306000^{\circ} \mathrm{S}, 90.451100^{\circ} \mathrm{W}\right)$, Galapagos Islands, Ecuador between March and August 1999 (see each subheading for specific dates). Supplementary work on adult wasp population dynamics was conducted from 1998 to 2001 on Santa Cruz Island (specific locations in section: Survey of $P$. versicolor adults through consecutive hot and cool seasons below).

Vegetation on both Floreana and Santa Cruz islands can be partitioned into up to four climatic zones (Wiggins and Porter 1971, Tye and Francisco-Ortega 2011): littoral, dry, transition, and humid. The elevation of these zones varies between islands and also varies according to the side of the island that is exposed to winds. In general, the leeward side of the islands have dry and transition zones that extend to higher elevations (Wiggins and Porter 1971, Trueman and d'Ozouville 2010). The littoral zone is a narrow coastal belt, which is characterized by salt-tolerant vegetation of mangroves, succulents, and salt-marsh grasses or sedges. Next follows the dry zone with arborescent Jasminocereus and Opuntia cacti, and seasonally deciduous trees in the genera Prosopis, Acacia, and Bursera. The dry zone typically extends up to $120-300 \mathrm{~m}$ above sea level (asl; Wiggins and Porter 1971). The transition zone receives more moisture than the dry zone and is characterized by deciduous woodlands dominated by the endemic Pisonia floribunda, Psidium galapageium, and the native Piscidia carthagenensis. In the highest elevation zone, the humid zone, vegetation varies between the two islands. On Santa Cruz Island, the humid zone starts at between $180 \mathrm{~m}$ asl (south slope) and $550 \mathrm{~m}$ asl (north slope) and includes four overlapping subdivisions: Scalesia pedunculata; brown or Zanthoxylum fagara; Miconia robinsoniana; and fern-sedge, which is found on top of the island from about 550 to $864 \mathrm{~m}$ asl (Wiggins and Porter 1971, Tye and Francisco-Ortega 2011). Much of the humid zone of Santa Cruz Island has been modified by agriculture and other human activities, especially by invasive plant species. On Floreana Island, the humid zone extends between 300 and $640 \mathrm{~m}$ asl and is subdivided into farmland, Scalesia pedunculata forest, and highland forest made up of a mix of native and introduced species (Dvorak et al. 2017). The climate experienced on the Galapagos Islands is unusually dry for the tropics, and the year can be divided into two main seasons: the hot season (January to May) with warmer air temperatures and sporadic heavy rain showers in both low- and high-elevation areas; and the cool season (June to December) when air temperature drops, and rainfall decreases at lower elevations, but the high-elevation zones remain almost constantly wet (Trueman and d'Ozouville 2010). 


\section{Distribution and Numbers of $P$. versicolor Colonies}

To determine the distribution and quantity of $P$. versicolor colonies by vegetation zone, study sites were selected that spanned the littoral, dry, transition, and humid zones on Santa Cruz and Floreana islands. On Santa Cruz Island, a total of 15 sites were selected: 3-littoral/ dry; 5-dry; 3-transition; and 4-humid zone. On Floreana Island, a total of 17 sites were selected: 2-littoral/dry; 4-dry; 4-transition; and 7-humid zone. In each vegetation zone, quadrats of $10 \times$ $10 \mathrm{~m}$ were randomly established. The following variables were recorded during June and July 1999: number of P. versicolor colonies (nests with individuals), number of empty nests (just the abandoned physical structure), number of nest cells, developmental phase of the nest, the tree species or human structure on which the nest was built, and nest height. The nests consist of a single uncovered comb so that its composition can be observed from the underside.

The wasp colony development phases were classified as pre-emergence phase-starts with the foundation of the new nest and ends with the emergence of the first adult wasp in that nest; post-emergence phase-a period in which the colony increases in physical and population structure until the appearance of reproductive forms; and the decline phase-characterized by ceasing nest expansion activities, irreversible reduction of the population, presence mainly of immature forms (eggs, larvae, and pupae) and the marked appearance of reproductive forms (males). Whenever possible, the number of adults, pupae, larvae, and eggs was counted or estimated.

Signs of predation by the introduced moth Taygete sphecophila (Meyrick) (Lepidoptera: Autostichidae) were recorded. This moth is known to attack P. versicolor in nests in Galapagos (discussed in Landry et al. 2006). The presence of this moth in the nests was determined by one of two ways; by the small holes that the moth pierces on the back of the nests to lay its eggs or by the distinctive breaches in the cells that the adult moth leaves when it emerges from the capped cells.

If a nest was found abandoned, it was collected and width, length, number of cells, and the length of the pedicel measured. All abandoned nests that showed signs of moth predation were placed in isolation boxes for $30 \mathrm{~d}$ at room temperature to identify adult moths that might emerge.

\section{Colony Dynamics of $P$. versicolor}

One colony was tracked during the different developmental phases to gather data on the survival of brood and adult P. versicolor in the dry zone of Santa Cruz Island. Nest maps were drawn daily from 27 April to 24 August 1999. The number of adults, pupae, larvae, eggs, and empty cells were recorded every day, as well as any other observable change in the colony. These observations were made during the evening or early morning, when no flight activity was observed, and it was assumed that the majority of adult wasps would be present.

In addition, colonies of $P$. versicolor were monitored at or near the Charles Darwin Research Station (CDRS) and in Puerto Ayora, the main town located on the south coast of Santa Cruz Island at 2-30 m asl, once a week between April and August 1999. In total, 69 colonies were tagged. For each colony, a nest map was drawn, and the number of eggs, larvae, pupae, adults, and empty cells recorded.

Polistes versicolor commonly feeds its larvae on lepidopteran larvae but they also consume beetle larvae, spiders, and other terrestrial invertebrates as they display an opportunistic-generalist foraging behavior (Prezoto et al. 2006, 2019). To determine prey availability in the vicinity of colonies in the dry zone at CDRS and relate this to wasp density, a group of 15 Sphingidae moth species (Roque-Albelo 2006) was chosen as a proxy of the seasonal abundance of Lepidoptera fauna as a whole. A single light trap (mercury vapor and UV) was set up twice a week between the end of April and mid-August 1999 at about $20 \mathrm{~m}$ asl. The light was installed just before sunset at 18:00, and all adult Sphingidae individuals coming to the trap from 22:00 until sunrise at 06:00 were recorded, marked, and released.

\section{Wasp Foraging Habits and Range}

All foraging studies were conducted in the dry zone of Santa Cruz Island near the CDRS between April and June 1999. To visually determine the proportion of different prey loads carried back to the nests by returning foragers, four different colonies were selected for observation. Each colony was observed once a week over 6 wk in total from 07:30 until 17:00 (the hours when P. versicolor was observed to be active), with half an hour break at 12:00. The foragers' loads were determined visually and recorded as prey, fiber or other if the wasp was carrying no visible load. Each of these four colonies had between 120 and 150 larvae on the first day of observation.

In three additional colonies, returning foragers that did not carry any prey items were collected with the aim of dissecting them and determining crop content. A total of 52 wasps were captured and placed in a killing jar with ethyl acetate. The wasps were dissected in the laboratory and the crop content examined visually for evidence of solid chewed prey (indicated by the presence of small flesh particles in the crop). If the crop contents were liquid, the sugar content of the liquid was tested with a Diastix reagent strip (Bayer, USA), which can detect glucose levels of at least $4-7 \mathrm{mmol} /$ liter. The liquid crop content of the wasp was considered to be water if the glucose test was negative, and nectar if the test was positive. During the same period, 49 returning foragers were collected from different colonies in the dry zone of Santa Cruz Island carrying a visible prey load. The prey items were identified to the level of insect order and life phase and their fresh and dry weight recorded. The presence of wood fiber for nest construction was also recorded.

To determine the foraging range of $P$. versicolor, yellow sheets of paper were glued on the underside of transparent plastic pans $(14 \times$ $21 \mathrm{~cm})$. These pans were used as sugar baits, filled with a sucrose solution (1:1 water:sugar), and placed at $50 \mathrm{~m}$ intervals along equidistant radians having as a starting point one of four different $P$. versicolor colonies. All wasps in each colony were marked with a dot of permanent textile paint on the dorsal side of the thorax using a brush with different colors for each colony (at dawn when all wasps were in the nest, prior to the beginning of the assays). The sugar baits were set out for three consecutive days for each of the four colonies, respectively, between the end of July and beginning of August 1999.

\section{Survey of $P$. versicolor Adults Through Consecutive Hot and Cool Seasons}

Wasp numbers were monitored at four localities on Santa Cruz Island for 1 wk each month for 29 mo, from November 1998 to March 2001. The four sites were: El Barranco $\left(0.742806^{\circ} \mathrm{S}, 90.302889^{\circ} \mathrm{W}\right.$, $15 \mathrm{~m}$ asl) and Tortuga Bay $\left(0.752778^{\circ} \mathrm{S}, 90.325222^{\circ} \mathrm{W}, 19 \mathrm{~m}\right.$ asl), both with dry zone vegetation; $\mathrm{Km} 27\left(0.581667^{\circ} \mathrm{S}, 90.365^{\circ} \mathrm{W} 350\right.$ $\mathrm{m}$ asl), a transition zone forest characterized by Piscidia carthagenensis and Bursera graveolens, and the only site on the northern slope of Santa Cruz Island, and Los Gemelos (0.626111 ${ }^{\circ} \mathrm{S}, 90.386111^{\circ}$ W, 500-600 m asl), a site in the humid Scalesia pedunculata forest. Eighteen yellow McPhail traps (BioQuip Products, CA) were placed in linear transects at $10-15 \mathrm{~m}$ intervals per site. The traps were filled with $200 \mathrm{ml}$ of a $10 \%$ molasses solution mixed with water and a couple of drops of dishwashing detergent. All wasps caught 
were identified and counted and the mean number of wasps per trap calculated. Average monthly rainfall data were obtained for El Barranco and Tortuga Bay from the meteorological station in Puerto Ayora (available at https:/www.darwinfoundation.org/en/ datazone/climate/puerto-ayora). For Los Gemelos and Km 27 the monthly volume of rainfall was recorded using a rainfall gauge, as these sites are located farther away from the existing weather stations. All reported summary statistics are means \pm standard errors in original scale.

\section{Results}

\section{Distribution and Numbers of $P$. versicolor Colonies}

Wasp colonies were found in the four vegetation zones of both the northwest slope of Floreana Island and the southern slope of Santa Cruz Island although the numbers of colonies in each zone varied (Table 1). During June and July 1999, the highest counts of colonies and empty nests combined were found in the dry zones of each island; 76.5 and $64.1 \%$ of all colonies and empty nests found on Santa Cruz and Floreana islands, respectively. The dry zone of Santa Cruz had the most colonies, whereas the highest number of colonies on Floreana was found in the humid zone. On Santa Cruz Island, the littoral/dry zone had the second highest count of colonies and empty nests combined, while low numbers were found in the transition and humid zones. In contrast, on Floreana Island, the second highest number of colonies and empty nests combined was measured in the humid zone, followed by the transition zone. No colonies (and only one empty nest) were found in the littoral/dry zone (Table 1).

Overall, a total of 346 colonies and empty nests in the three developmental phases were counted in June and July 1999 (162 on Santa Cruz Island and 184 on Floreana Island). Ninety-seven colonies and nests were in the pre-emergence phase $(49.5 \%$ colonies, $50.5 \%$ empty nests). These nests were small (average dimensions $1.20 \mathrm{~cm}$ wide $\times 1.81 \mathrm{~cm}$ long) and were composed of a few cells (average: 11.23 cells/nest). The post-emergence phase was well represented with 247 colonies and nests $(42.5 \%$ colonies, $57.5 \%$ empty nests). Nest dimensions averaged $20.57 \mathrm{~cm}$ wide and $29.92 \mathrm{~cm}$ long. The number of cells in this phase ranged from 12 to 251, with an average of 100 cells/nest. Only two colonies were found in the decline phase during the time of the fieldwork, both in the dry zone of Floreana Island.

In Galapagos, colonies of P. versicolor were founded by one to five foundresses, with an average of 2.05 foundresses per colony. All nests were supported by a single pedicel with an average length of $5.5 \mathrm{~mm}$. The nests were built on trees, shrubs, and on various

Table 1. Number of colonies (nests with individuals) and empty nests (physical structure without wasps) found per vegetation zone during June and July 1999 in two Galapagos islands

\begin{tabular}{llrrc}
\hline Island & Zone & $\begin{array}{c}\text { Total number of } \\
\text { colonies and nests }\end{array}$ & Colonies & Empty nests \\
\hline SC & Littoral/dry & 29 & 9 & 20 \\
SC & Dry & 124 & 74 & 50 \\
SC & Transition & 5 & 1 & 4 \\
SC & Humid & 4 & 2 & 2 \\
FL & Littoral/dry & 1 & 0 & 1 \\
FL & Dry & 118 & 25 & 93 \\
FL & Transition & 19 & 8 & 11 \\
FL & Humid & 46 & 34 & 12 \\
\hline
\end{tabular}

SC, Santa Cruz; FL, Floreana. human-made structures (Fig. 1). The highest number of nests $(37.57 \%)$ were found on human-made structures, in particular roof overhangs, and were attached to wood, plastic, cement, iron, and other substrates. A large proportion of nests on human structures were found in the dry zones, which are associated with human settlements $(35 \%$ of nests on Santa Cruz Island and $85.6 \%$ of nests on Floreana Island). Acacia macracantha, a dry zone plant, was the second preferred substrate after human-made structures $(19.94 \%$; Fig. 1). The pedicels of most of the nests built on branches of A. macracantha were constructed directly on thorns. The third preferred nesting site for $P$. versicolor was on Zanthoxylum fagara, a transition and humid zone tree species. Polistes versicolor built their nests at heights ranging from $0.2 \mathrm{~m}$ to $9.5 \mathrm{~m}$ from the ground. More than $85 \%$ of the nests were found at a height between 1.5 and $3.5 \mathrm{~m}$.

\section{Colony Dynamics of $P$. versicolor}

In the lowland dry zone of Santa Cruz Island, the first major rainfall of the hot season in 1999 began on 3 March. Over $2 \mathrm{~d}$, more than $25 \%$ of the total rainfall amount reported for the whole year was recorded (Fig. 2). Less severe rainfalls were recorded in the following months. The number of colonies recorded in the study area reached a peak of 40 in May, with the number of newly formed colonies (in the pre-emergence phase) and colonies in the post-emergence phase decreasing as the hot season transitioned into the cool season (June onwards; Fig. 2A). Similarly, the mean number of pupae per colony was highest in May, but then decreased steeply until it reached a plateau at the end of July (Fig. 2B). The mean number of occupied cells per colony increased until the first week of June, and then decreased gradually until the end of the observational period, in late August (Fig. 2B). No new colonies were established from June onwards, and numerous nests appeared to have been abandoned. By the end of August, when air temperatures were at the lowest during the study, only 16 colonies were counted. Polistes versicolor colony development followed the number of adult Sphingidae moths captured at night (Fig. 3). The highest number of adult moths caught was at the end of April and by mid-July moths were only found in very low numbers. This suggests that moth development (and the presence of caterpillars) coincided with the period of growth of $P$. versicolor colonies.

The daily development of one colony was followed in the lowland dry zone of Santa Cruz Island. This colony produced 222 adults from 427 eggs during the period 27 April to 24 August 1999. The colony size (total number of cells) as well as the number of individuals in each developmental size increased steadily from the beginning of April to mid-June/beginning of July and then either plateaued or decreased. The colony attained its maximum number of 253 cells on 1 July 1999, whereas the highest number of adult foraging wasps (36) was recorded on 6 July 1999 (Fig. 4). At that point, the colony stopped growing; i.e., no new cells were produced, and the number of foraging adults decreased. The cells no longer contained viable eggs and there was a higher level of mortality of larvae.

The introduced predatory moth species T. sphecophila was present in nests of $P$. versicolor on both islands (reviewed by Landry et al. 2006). Signs of infestation of T. sphecophila could be observed in both $P$. versicolor colonies and empty nests. Colonies in the post-emergence phase appeared to be more susceptible to T. sphecophila infestation (88\% of colonies) than colonies in the pre-emergence phase (12\% of colonies). Our observations suggest that nests built on human-made structures (in inhabited areas of both islands) were less susceptible to T. sphecophila (up to $21 \%$ of colonies presented signs of moth predation) than nests built on trees or shrubs in vegetated areas (up to $63.2 \%$ of colonies presented signs of moth 


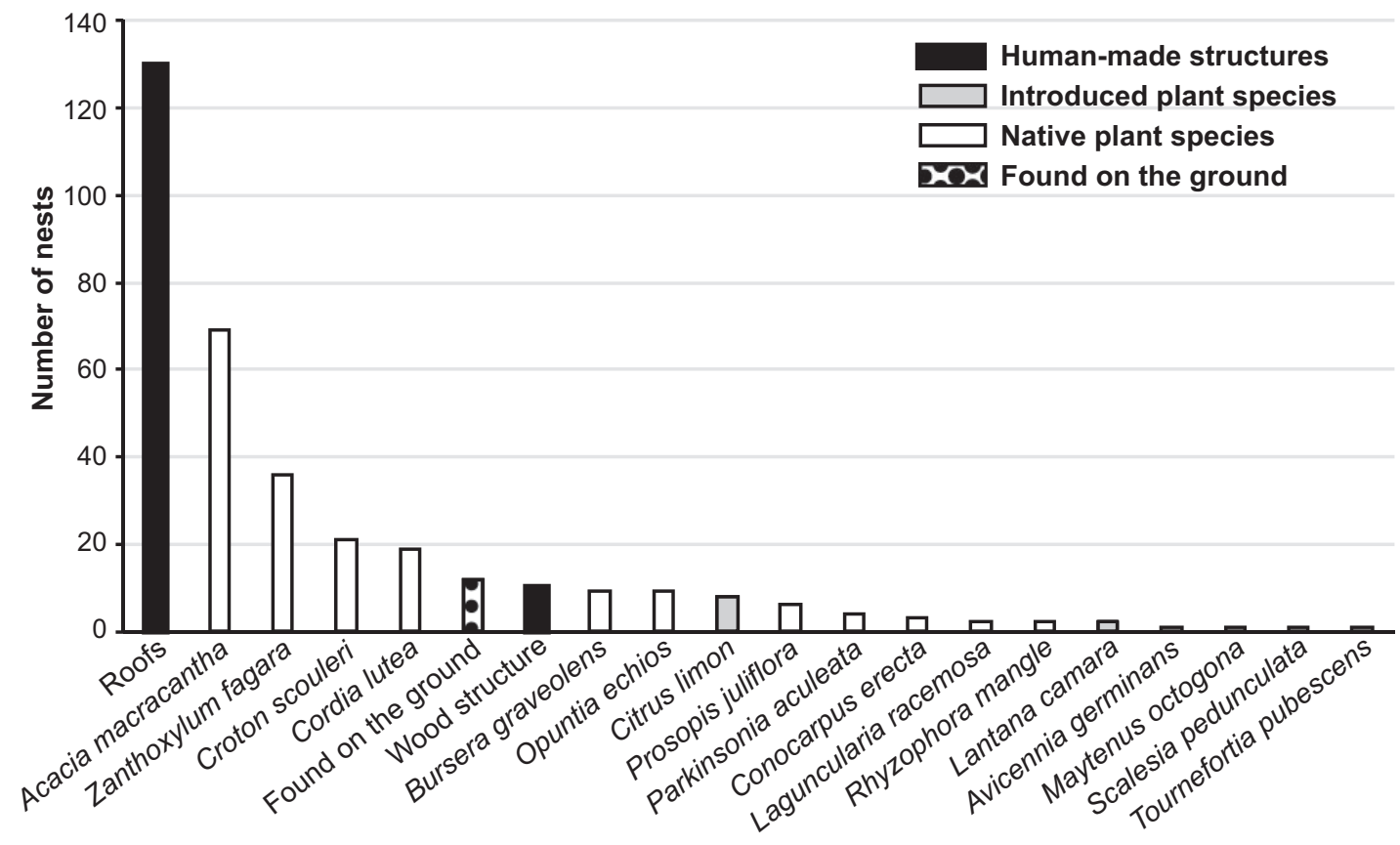

Fig. 1. Plant species or man-made structures utilized as nest supports by P. versicolor to hang their nests on Floreana and Santa Cruz Islands, Galapagos; $n=346$ nests.

predation). On Santa Cruz Island, the presence of T. sphecophila was limited to the dry zone, whereas on Floreana Island more than $50 \%$ of the colonies found in the transition and humid zones presented signs of T. sphecophila. The only moth species that emerged from the 22 nests placed in isolation was T. sphecophila. We did not observe any evidence of hymenopteran parasitoids.

Other natural enemies of $P$. versicolor in Galapagos include the predatory fire ant, W. auropunctata, which was found on nine occasions in $P$. versicolor colonies. Spiders were occasionally found in abandoned nests but never in colonies. Eleven nests were destroyed, and it is likely that birds were responsible, eight of these presented signs of T. sphecophila damage. In addition, in January 1999, two wasps mummified by an unidentified fungus resembling Metarbizium spp. Sorokīn (Hypocreales: Clavicipitaceae) were found on Floreana Island.

\section{Wasp Foraging Habits and Range}

Of the 140 wasps from four different colonies that were caught in the sugar baits over a period of $3 \mathrm{~d}, 91.4 \%$ were caught within 200 $\mathrm{m}$ of their colony, and $8.6 \%$ were at a distance of $250 \mathrm{~m}$ up to $300 \mathrm{~m}$.

Polistes versicolor was observed in the field foraging for four types of resources. Wasps collected fiber from the vegetation, waste paper, and less often wood structures, to use as building materials for their nests. Wasps removed thin layers of fiber, forming a small pellet, which was then carried back to the colony in their mandibles. Sometimes, the same individual wasps were observed repeatedly returning to the same fiber source. Polistes versicolor wasps were observed collecting liquid at various sources of water, including brackish water.

In addition, wasps were observed visiting flowers of 67 plant species (Supp Table 2 [online only]). The wasps were also observed collecting the extra nectary secretions of Maytenus octogona (L'Hér.) DC. (Celastrales: Celastraceae) trees and collecting the honeydew of aphids. Once back at the nest, the returning foragers often shared their loads of nectar or water with one or more wasps via trophallaxis.

Returning foragers either carried solids in their mandibles or their mandibles were empty and they carried liquid or chewed prey in their crops (nectar or water or flesh particles of prey with liquid). No forager sampled had both empty mandibles and an empty crop. Of the 52 foragers returning to the colony with empty mandibles, $52 \%$ were carrying water in their crops, $35 \%$ were carrying nectar, and $13 \%$ were carrying flesh particles of prey. No incoming foragers were observed with a mixed load of fiber and flesh in their mandibles. However, it is possible that some foragers were transporting a load both in their mandibles and in the crop; this behavior was not verified. In total, 49 prey loads were collected from foraging wasps from four other colonies that were monitored. The mean fresh weight of a prey load was $17.46 \mathrm{mg}$ $( \pm 1.49$ ). The smallest prey load was $8.2 \mathrm{mg}$ fresh weight and the largest was $33.5 \mathrm{mg}$ fresh weight. If the prey was too large for the forager to carry, it would cut it into pieces and carry it in two or more trips.

Once the prey was found and killed, the wasp dissected it, removing apparently undesired parts such as the head and legs. Of the flesh loads that were collected from the mandibles of returning foragers and examined, Lepidoptera larvae accounted for the largest proportion of identifiable prey ( $46 \%$; Table 2$)$. Other prey included spiders $(16 \%)$, beetles $(8 \%)$, flies and gastropods $(3 \%)$, and Hemiptera $(2 \%)$.

Table 3 presents the mean number of times that returning foragers carried prey, fiber or crop loads (nonvisible external load) back to four colonies that were monitored $1 \mathrm{~d}$ each week for $6 \mathrm{wk}$. Crop loads containing either water or nectar were brought back to the colonies more often (mean: $82.33 \pm 0.82$ times a day) followed by insect prey (mean: $18.83 \pm 0.69$ times per day) and fiber loads for nest construction (mean: $6.46 \pm 0.12$ times per day). In total, foragers in a colony carried out between 85 and 121 trips per day. Given that the average fresh weight of the prey loads was $17.46 \mathrm{mg}$ and that $P$. versicolor carried loads back on average 18.83 times a day, this means that an average of $328.77 \mathrm{mg}$ of fresh prey was brought to the nest per foraging day for a typical colony of 120-150 larvae. 

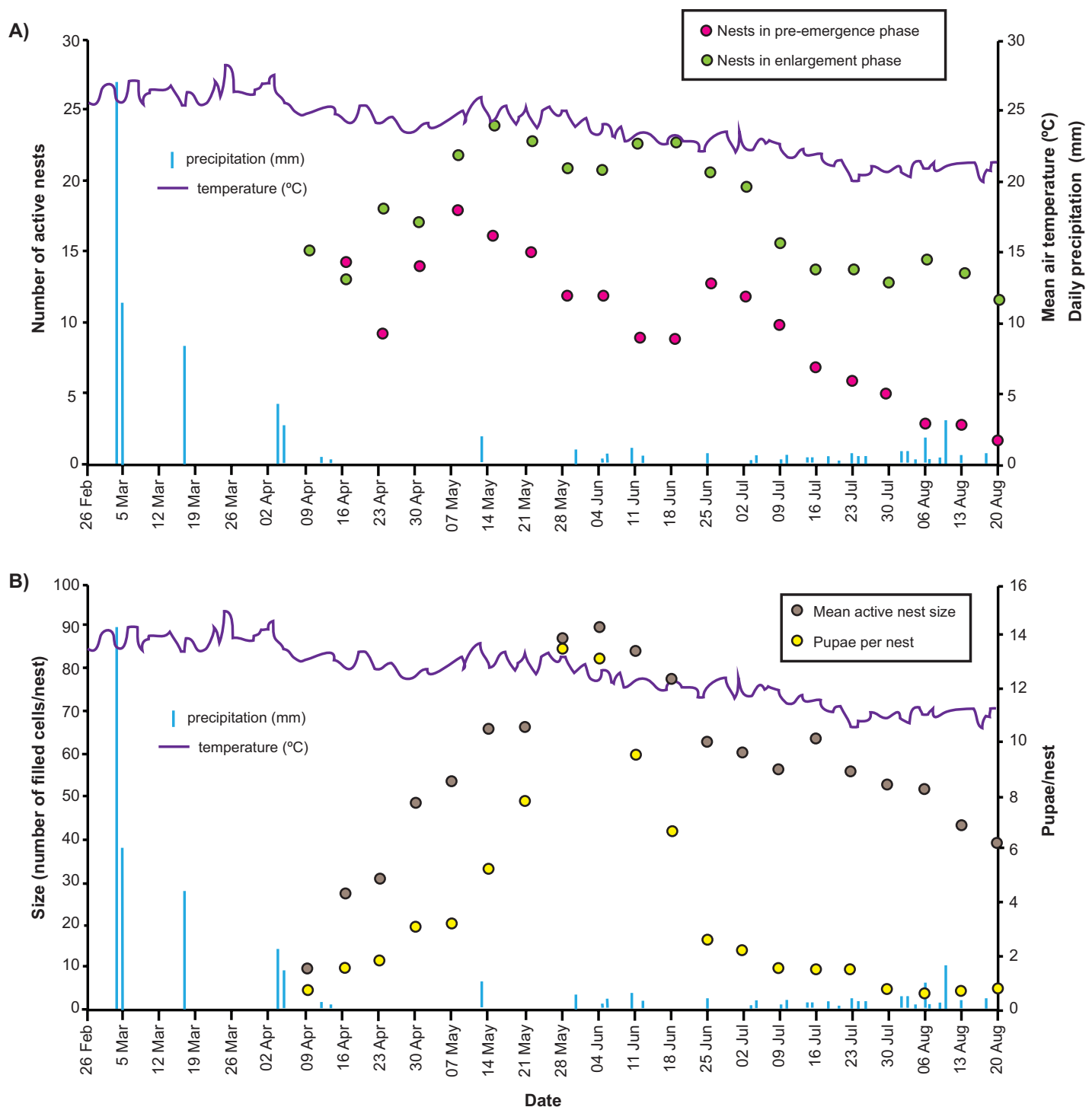

Fig. 2. (A) Number of $P$. versicolor colonies followed weekly from April to August 1999. (B) Mean colony size, defined as the number of filled cells per nest, and the number of pupae per colony ( $n=69$ colonies). Values for mean air temperature and the amount of daily precipitation for both panels are scaled to the secondary $y$-axis on $(A)$ and traced on $(B)$ for reference.

\section{Survey of $P$. versicolor Adults Through Consecutive Hot and Cool Seasons}

Adult wasp abundance differed at the four sites monitored with 18 traps on Santa Cruz Island between 1998 and 2001. For El Barranco and Tortuga Bay, both sites near sea level in the dry zone, overall wasp numbers decreased during the hot season and slightly increased during the cool season (shown with gray boxes in Fig. 5), but wasp numbers were low overall. The mean number of wasps per trap at El Barranco was $3.78 \pm 0.60$ and $2.95 \pm 1.10$ wasps per trap at Tortuga Bay for the 29-mo period (Fig. 5A). The highland site, Los Gemelos, did not appear to support high numbers of paper wasps (average $0.60 \pm 0.18$ wasps per trap), as for most months no wasps were caught in the traps with a maximum mean number of 4.11 wasps per trap recorded in June 1999. The fourth site, $\mathrm{Km} \mathrm{27}$, presented the highest number of wasps surveyed. At this site, wasp numbers notably increased following the hot season with a mean of 39.6 wasps per trap in June 1999 and 50.8 wasps per trap in July 2000 (Fig. 5B).

\section{Discussion}

Polistes versicolor demonstrated a great ability to quickly adapt its life cycle habits to the conditions of the Galapagos Islands. The wasps found in the flora and invertebrate fauna all they needed to survive and establish themselves on the islands showing a preference for the drier habitats over the wetter highland areas. Wasp developmental cycles appear to be seasonally synchronized, with nesting activity following the rains in the hot season (typically between January and May) and peaks in numbers of adults in the cool season when there is barely any rain in the drier zones (June-December) (Trueman and d'Ozouville 2010).

Reproduction of many species in the Galapagos Islands is determined by the frequency and quantity of rains that fall in the hot season and the resources that become available following this period (Lack 1947, Grant 1986). Polistes versicolor appears to have adapted to this regimen. In 1999, wasp nesting activity increased following periods of intense rainfall in March. High precipitation in the hot season in Galapagos usually triggers new 


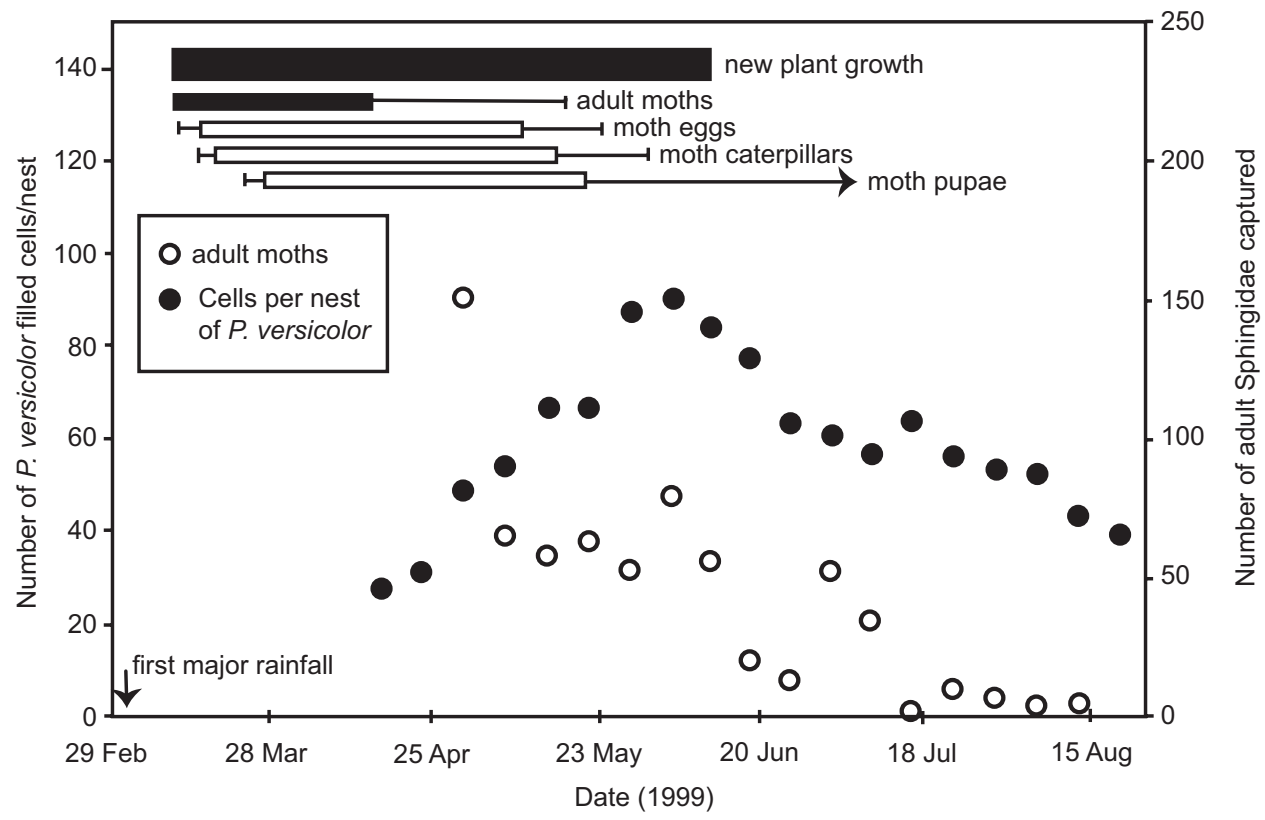

Fig. 3. Polistes versicolor colony size increase (measured as the number of occupied cells per colony; filled circles) versus the increase in number of adult Sphingidae moths captured at night. The first major rainfall of the hot season occurred on 3 March 1999 as indicated by the arrow on the x-axis. This rainfall triggered a period of new plant growth (illustrated by a hypothetical band), which starts usually a few days following the rainfall. The rainfall triggered an explosion in plant-eating insects, including Lepidoptera larvae. Here, it is illustrated by the consequent increase in the number of sphingid moths captured at night (open circles). The approximate time when the moth egg, larval, and pupal phases were present was inferred from the captured adult moths and other studies (Bell and Joachim 1976, Roque-Albelo 2006).

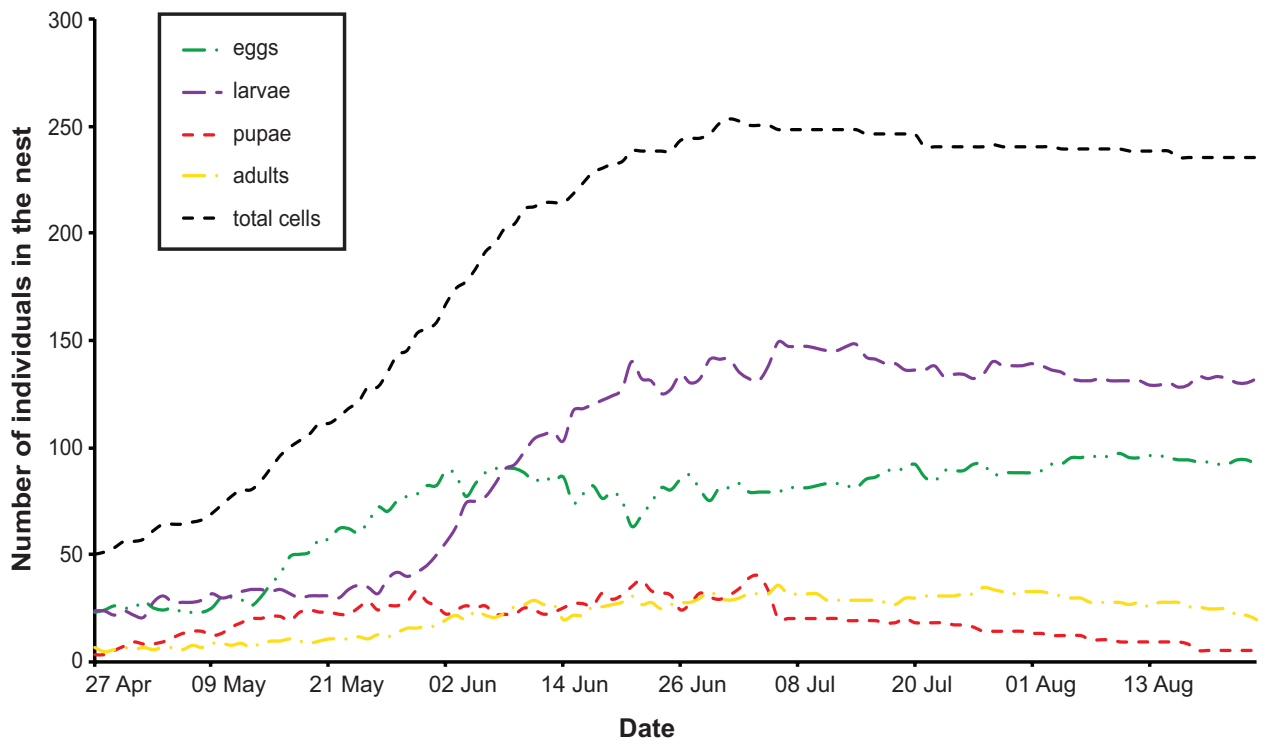

Fig. 4. Development of an individual P. versicolor colony that was tracked daily from April to August 1999.

plant growth and an increase in insect abundance (Roque-Albelo and Causton 1999, Peck 2006). This includes plant-feeding caterpillars, the prey item collected more often by $P$. versicolor in our study. The monitoring of Sphingidae as an indicator for other insects suggested that adults emerged from their pupae and started to reproduce in the days following the first major rainfall. This pattern was confirmed by studies carried out between 1999 and 2001 (Roque-Albelo 2006). The life cycle of Sphingidae takes ca. $30 \mathrm{~d}$ from egg to the last larval instar (Bell and Joachim 1976) thus it appears that the presence of moths in the larval phase (caterpillars) coincided with the period of growth of $P$. versicolor colonies reaching maximum numbers at the end of May. Wasp colonies stopped growing as temperatures declined in the transition to the cool season (associated with little or no rainfall in the dry zones) and the boom of insects was over. Coincidentally, the fact that only two colonies were found in the decline phase during the time of the fieldwork could mean that colonies start to produce drones and reproduce after July.

A general trend of low adult wasp numbers in traps during the hot season and an increase in wasp numbers in the cool season was 
observed in the 29-mo wasp trapping program at four different altitudinal sites on Santa Cruz Island. This is in line with our findings of peak colony production at the end of the hot season. It should be noted that wasp numbers, in particular in 1999, may have been influenced by the 1997-1998 El Niño event which was associated with higher than normal rainfall for extended periods (Trueman and d'Ozouville 2010). The mid-elevation site, $\mathrm{Km} \mathrm{27,} \mathrm{located} \mathrm{on} \mathrm{the}$ northern slope on the leeward side of Santa Cruz Island, typically dry with a mix of arid zone and transition zone vegetation (Wiggins and Porter 1971, Tye and Francisco-Ortega 2011), presented the highest number of wasps year-round, in particular at the beginning of the cool season (June and July) in both 1999 and 2000. On the other hand, very low wasp numbers were trapped at the humid highland site, Los Gemelos. Colony and plant visitation surveys in 1992/1993 (Laso-Vacca 1997), did not observe any wasp activity at Los Gemelos and it is likely that the wetter and colder climate at this site is less appealing to wasps than the drier sites.

Colony density studies during the first part of the cool season in 1999 also suggest a preference for the drier vegetation zones. A greater number of wasp colonies and empty nests were found in the dry zone on the southern slope of Santa Cruz Island where conditions in the cool season are typically rain-free; compared with the transition and humid zones that experience wetter conditions (Trueman and d'Ozouville 2010). On the north-western slope of Floreana Island, the highest number of colonies and empty nests combined was recorded in the dry zone though the highest number of colonies was in the humid zone followed by the dry zone. The northern slopes of the high elevation islands are typically drier than the southern slopes (Trueman and d'Ozouville 2010) and may explain this difference between islands. A similar study in the hot season in 1993 (Lasso-Vaca 1997) found the highest colony densities

Table 2. Percent of categories of prey items in flesh loads of returning $P$. versicolor foragers collected in the dry zone of Santa Cruz Island during April and June 1999

\begin{tabular}{lc}
\hline Prey & Percent of loads $(\%)$ \\
\hline Insects & \\
$\quad$ Coleoptera & 8 \\
Diptera (adults) & 3 \\
Hemiptera & 2 \\
$\quad$ Lepidoptera (larvae) & 46 \\
Other invertebrates & \\
Aranaeae & 16 \\
Gastropoda & 3 \\
$\quad$ Unknown & 22 \\
Total loads & 100 \\
\hline
\end{tabular}

in the dry zone of Santa Cruz Island, followed by the agricultural zone, whereas in Floreana Island, the transition zone presented the highest number of colonies, followed by the dry zone (Lasso-Vaca 1997). In summary, both studies indicated a preference for drier areas, the differences in wasp densities in the vegetation zones may be due to climate differences in that year.

On both islands, the high prevalence of $P$. versicolor colonies in the dry zones may be in part due to the presence of human settlements; a high proportion of nests were built under roof overhangs or other human-made structures suggesting that $P$. versicolor takes advantage of the protection from adverse weather and predators provided by these structures as found in other parts of South America (Reed and Vinson 1979, Ramos and Diniz 1993, de Oliveira et al. 2010). Across its wide geographical range from Costa Rica to Argentina, P. versicolor seems to prefer dry forest habitats (Richards 1978), and it has also been shown to prefer urban areas over natural vegetated habitats (Ramos and Diniz 1993). The greater abundance of wasps in and near inhabited areas may also in part be explained by availability of rainwater collected for human needs. Comparing colony densities in the vegetation zones of inhabited versus uninhabited high-elevation islands would be a way of verifying whether human settlements foster colony establishment. An important parameter to include in such a study is the number of foundresses. Galapagos colonies of $P$. versicolor were founded by one to five foundresses. In a study on colony foundation of $P$. simillimus Zikán (Hymenoptera: Vespidae), founding events in an anthropogenic environment were mostly by solitary females (Prezoto et al. 2015). The authors hypothesized that ecological constraints are reduced in these environments and wasps are able to take advantage of this situation to found more nests through isolated foundings.

Observations on Floreana Island (Lasso-Vaca 1997) suggest that high numbers of adult wasps are not necessarily only associated with the areas they nest in. At a site in the littoral zone, approximately 1,000 wasps were observed visiting plants in May 1992, but no nests were found. Furthermore, high wasp numbers are often reported by naturalist guides at a tourist visitor site on the coast, Post Office Bay. In our study, most wasps foraged within $200 \mathrm{~m}$ of the nest, comparable to the foraging range of other P. versicolor and other Polistes species (Dew and Michener 1978, Prezoto et al. 2007). Additional studies are required to study foraging range under different conditions to further understand foraging capacity.

\section{Impact on Galapagos Ecosystems}

Almost half of the prey loads of $P$. versicolor were made up of Lepidoptera larvae. The rest of the prey loads consisted of other invertebrates including gastropods and beetles. In Galapagos, about $75 \%$ of Lepidoptera are indigenous to the islands (Roque-Albelo and

Table 3. Mean number of times $P$. versicolor foragers were observed carrying different types of loads (visually identified) back to their colonies ( $n=4$ colonies)

\begin{tabular}{lcccc}
\hline Date & Fiber & Prey & Crop load & Mean number of visits per day \\
\hline Day 1 & $5.50 \pm 0.96$ & $18.75 \pm 1.50$ & $86.25 \pm 2.60$ & $110.50 \pm 4.94$ \\
Day 8 & $8.00 \pm 0.71$ & $20.25 \pm 1.80$ & $83.50 \pm 4.79$ & $111.75 \pm 5.36$ \\
Day 15 & $6.00 \pm 1.35$ & $17.25 \pm 1.03$ & $80.75 \pm 6.17$ & $104.00 \pm 7.85$ \\
Day 22 & $5.50 \pm 0.86$ & $18.75 \pm 2.62$ & $79.50 \pm 1.55$ & $103.75 \pm 4.77$ \\
Day 29 & $6.25 \pm 1.44$ & $20.50 \pm 1.50$ & $84.75 \pm 6.66$ & $111.50 \pm 8.84$ \\
Day 36 & $7.50 \pm 1.26$ & $17.50 \pm 1.85$ & $79.25 \pm 3.54$ & $104.25 \pm 5.70$ \\
\hline
\end{tabular}

The load of every returning forager was classified as prey, fiber, or crop load (if the wasp was carrying no visible load). Colonies were monitored from 07:30 until 17:00. All four colonies had between 120 and 150 larvae on the first day of observation. 

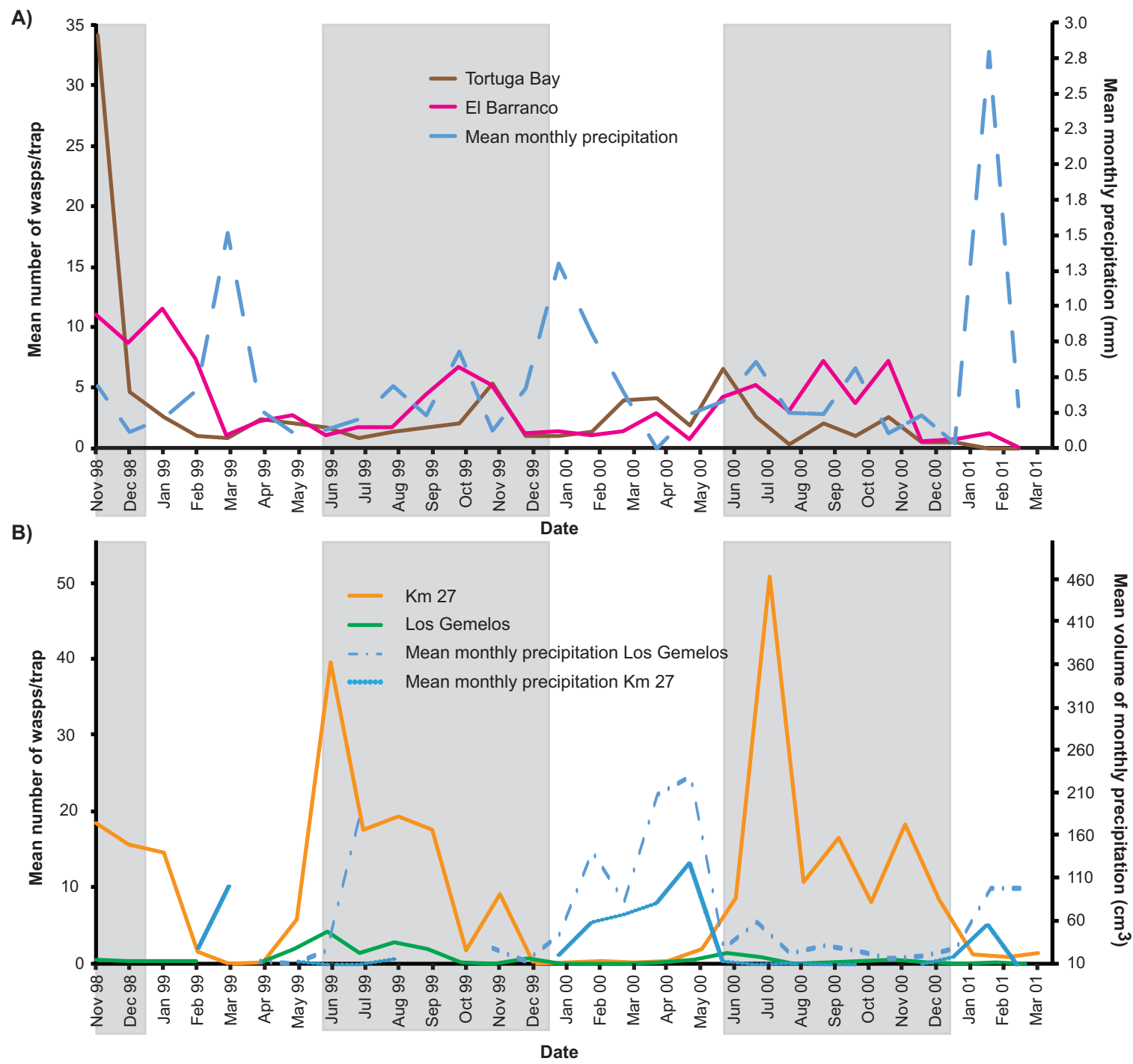

Fig. 5. Mean monthly number of $P$. versicolor adults collected in McPhail traps during 29 mo of monitoring. (A) Tortuga Bay and El Barranco, two dry zone sites. (B) $\mathrm{Km} 27$ (transition zone) and Los Gemelos (humid zone). Gray boxes represent the cool season (June to December). Note that the rainfall units for (A) are millimeters, whereas for (B), the rainfall volume is in cubic centimeters.

Landry 2018), thus, it is likely that a large component of prey is made up of native or endemic species. A preference for lepidopteran larvae was also observed in two studies in Brazil where $>95 \%$ of the prey items captured were leaf-eating lepidopterans (Prezoto et al. 2006, Elisei et al. 2010), where each $P$. versicolor colony was estimated to capture approximately 4,015 prey items per year (Prezoto et al. 2006). The propensity for lepidopteran prey may be due to availability rather than preference. Our study in Galapagos was conducted during the rainy season when Lepidopteran larvae were abundant. A study on foraging behavior of social wasps in different environments in Brazil, found that social wasps preyed on Lepidoptera in higher proportions on small farms, probably due to their higher abundance in farming environments, but wasps, including $P$. versicolor, had a greater diversity of prey in urban gardens (Prezoto et al. 2019). This result agrees with the opportunistic-generalistic foraging behavior described for social wasps (Raveret Ritcher 2000).

In the Galapagos Islands, with an average of 18.8 trips per day, an estimated average of $328.77 \mathrm{mg}$ of fresh insect prey was captured per day for a colony of 120-150 wasp larvae in the dry zone. Considering that wasps typically forage within a $200 \mathrm{~m}$ radius and that more than one colony can be found within this radius, the impact on the invertebrates in a given area is, therefore, expected to be quite high. These predation events also likely impact other species that depend on insects such as the strictly insectivorous vertebrates: 15 species of land birds, including eight Darwin's finches, nine gecko species, and nine lava lizards (Supp Table 1 [online only]). Before the arrival of $P$. versicolor to the archipelago, food abundance was already a limiting factor for some insectivorous finch populations (Grant 1986). Grant and Grant (1997) suggested that the population decline in the rarest of Darwin's finches, the mangrove finch (Camarhynchus heliobates) (Snodgras \& Heller) (Passeriformes: Thraupidae), was at least partly due to the presence of high numbers of P. versicolor, as a competitor for food in the ecosystem. The authors hypothesized that by using part of the same food supply (insect larvae), the wasps reduced food resources that were already scarce. In the 20+ yr since the Grant and Grant (1997) study, the mangrove finch population has declined further, but primarily due to the effect of another recent invader, a nest parasitic fly (Philornis downsi; reviewed by Fessl et al. 2018). The extent of the role of P. versicolor in the documented mangrove finch decline is unknown and studies are required to determine its influence. 
The effects of P. versicolor on Galapagos invertebrates might not be limited to their predation pressure only. Polistes versicolor regularly visit flowers to feed on nectar and future studies need to evaluate whether this wasp competes with native pollinators (Traveset et al. 2013, Hervías-Parejo and Traveset 2018). Their effectiveness in aiding in the pollination of endemic and introduced plants species also merits further studies (Traveset et al. 2013). Data compiled from our study and five additional studies provide evidence of $P$. versicolor visiting at least 93 plant species in the Galapagos Islands, including 27 introduced plants. In one of these studies, $P$. versicolor was considered one of the highest insect visitors of flowers of Cryptocarpus pyriformis Kunth (Caryophyllales: Nyctaginaceae) and Waltheria ovata Cav. (Malvales: Sterculiaceae) (Hervías-Parejo and Traveset 2018). In another study in the Galapagos Islands, P. versicolor was recorded getting nectar and biting the inflorescence peduncles and fruits to get liquid of the introduced Lantana camara L. (Lamiales: Verbenaceae) shrub (Carrión-Tacuri et al. 2014). Flower visitation of a broad range of plant species has also been recorded in Brazil (Köhler 2008).

For humans, $P$. versicolor is best known for its sting that can cause severe allergic reactions. The wasp is commonly found in large numbers at tourist visitor sites, vegetable markets and farms. In years when climatic conditions are highly favorable for wasp reproduction, wasp numbers have been exceptionally high, seriously affecting tourism at certain visitor sites as well as activities in human settlements.

Although no studies have been conducted on the status of P. versicolor in the Galapagos Islands since the ones reported here, reports submitted to the Galapagos National Park Directorate (D. Rueda, personal communication) suggest that this wasp continues to be a nuisance to residents and tourists alike. We recommend more studies to determine population trends, ecological consequences, and current distribution of this wasp in the Galapagos Islands.

\section{Natural Enemies, a Tool for Management?}

The absence of natural enemies in the introduced range of a species can enable it to flourish (enemy release hypothesis; Keane and Crawley 2002_see Engelkes and Mills 2011). This appears to be the case with $P$. versicolor in the Galapagos Islands. Colonies were relatively free from natural enemies. Although predators such as ants, birds, rats, and mice destroyed some colonies, most of the colonies that were attacked had already been infested by the predatory moth T. sphecophila. The potential for this moth to control P. versicolor in Galapagos, however, was determined to be low because it is most commonly associated with colonies in an advanced phase and does not cause colony failure (this study, Landry et al. 2006).

Much still has to be learned about the natural enemies associated with Neotropical social wasps, their host range and their impacts (Kudô et al. 2013, Somavilla et al. 2015). Parasitoid species reported in $P$. versicolor nests elsewhere include the gregarious ectoparasitoid Elasmus polistis Burks (Hymenoptera: Eulophidae) and the solitary icheumonid wasp, Pachysomoides sp. (Hymenoptera: Ichneumonidae), both of which are known to parasitize prepupae and pupae in wasp colonies in Brazil (Dorfey and Köhler 2011, de Souza Tavares et al. 2013).

Two instances of a fungus, that appeared to be Metarhyzium spp. are reported in this study infesting $P$. versicolor adults in Galapagos. The species or prevalence of this pathogen is not known. More recently, the fungus Hirsutella saussurei (Cooke) Speare (Hypocreales: Ophiocordycipitaceae) was found parasitizing nine yellow paper wasps on Floreana and Santa Cruz islands, Galapagos (Mollá et al. 2020).
This is the first time this species has been reported in the Galapagos Islands. This fungus is the asexual form of Ophiocordyceps humbertii (C.P. Robin) Sung et al. (Hypocreales: Ophiocordycipitaceae), which was found infecting 14 social wasp species in Brazil (Somavilla et al. 2020). Extensive research is still required to better understand entomopathogenic fungi associated with social wasps in South America and their impact on these species (Montalva et al. 2017).

Lastly, $P$. versicolor adults can also serve as prey for some species in the Galapagos Islands. Wasps have been found in the stomach contents of the smooth-billed ani, Crotophaga ani L. (Cuculiformes: Cuculidae), an invasive species that is a predator of invertebrates and vertebrates as well as a disperser of invasive plant seeds (Cooke et al. 2020). There is also some evidence to suggest that the wasps are prey items of Galapagos species; endemic mockingbirds and lizards have been observed feeding on live P. versicolor that have been discarded after removal from traps.

\section{Conclusions}

The information presented here provides important information about the ecology and distribution of $P$. versicolor and will inform the development of a management program for this invasive species in the archipelago. Both the native fauna (insectivorous animals and the herbivorous insects that are the prey of these wasps) and the Galapagos people (tour companies, visitors, and residents) will benefit from reduced wasp numbers.

\section{Supplementary data}

Supplementary data are available at Environmental Entomology online.

\section{Acknowledgments}

Our special thanks go to the Galapagos National Park Directorate for issuing investigation permits and for field and logistical support. We thank Jacqueline Rodríguez for digitalizing the trapping data and the many volunteers involved in the wasp studies between 1998 and 2001. Heinke Jäger kindly revised the list of plants in Supp Table 2 (online only). We also thank two anonymous referees for their useful comments that improved our manuscript. The field work was supported by Discovery Grants from the Natural Sciences and Engineering Research Council of Canada to SBP and the Canadian International Development Agency to CEP while both were with the Department of Biology, Carleton University, Ottawa, Ontario, Canada. The wasp monitoring work was financially supported by Galapagos Conservancy, Lindblad Expeditions-National Geographic Fund, and the British Embassy. The writing of this manuscript was supported by a grant from the Galapagos Conservancy to P.J.L. and M.B. This is contribution number 2351 of the Charles Darwin Foundation for the Galapagos Islands.

\section{References Cited}

Abedrabbo, S. 1991. Nueva avispa introducida en las Islas Galápagos. Carta Informativa. 31: 4.

Bell, R. A., and F. G. Joachim. 1976. Techniques for rearing laboratory colonies of tobacco hornworms and pink bollworms. Ann. Entomol. Soc. Am. 69: 365-373.

Bellard, C., J. F. Rysman, B. Leroy, C. Claud, and G. M. Mace. 2017. A global picture of biological invasion threat on islands. Nat. Ecol. Evol. 1: 1862-1869.

Carrión-Tacuri, J., R. Berjano, G. Guerrero, E. Figueroa, A. Tye, and J. M. Castillo. 2014. Fruit set and the diurnal pollinators of the invasive Lantana camara and the endemic Lantana peduncularis in the Galapagos Islands. Weed Biol. Manag. 14: 209-219.

Causton, C. E., and C. Sevilla. 2007. Latest records of introduced invertebrates in Galapagos and measures to control them. Galapagos Report 2006-2007. CDF, GNP and INGALA, Puerto Ayora, Galapagos, Ecuador. 
Causton, C. E., S. B. Peck, B. J. Sinclair, L. Roque-Albelo, C. J. Hodgson, and B. Landry. 2006. Alien insects: threats and implications for conservation of Galapagos Islands. Ann. Entomol. Soc. Am. 99: 121-143.

Charles Darwin Foundation (CDF) and WWF-Ecuador. 2018. The Atlas of Galápagos, Ecuador: native and invasive species. CDF and WWF-Ecuador, Quito.

Cooke, S. C., D. Anchundia, E. Caton, L. E. Haskell, H. Jäger, Y. Kalki, Ó. Mollá, J. Rodríguez, T. D. Schramer, A. Walentowitz, et al. 2020. Endemic species predation by the introduced smooth-billed ani in Galápagos. Biol. Invasions. 22: 2113-2120.

Dew, H. E., and C. D. Michener. 1978. Foraging flights of two species of Polistes wasps (Hymenoptera: Vespidae). J. Kansas Entomol. Soc. 51: 380-385.

Dorfey, C., and A. Köhler. 2011. First report of Elasmus polistis Burks (Hymenoptera: Eulophidae) recovered from Polistes versicolor (Olivier) (Hymenoptera: Vespidae) nests in Brazil. Neotrop. Entomol. 40: 515-516.

Dvorak, M., E. Nemeth, B. Wendelin, P. Herrera, D. Mosquera, D. Anchundia, C. Sevilla, S. Tebbich, and B. Fessl. 2017. Conservation status of landbirds on Floreana: the smallest inhabited Galápagos Island. J. Field Ornithol. 88: 132-145.

Elisei, T., J. V. E. Nunes, C. Ribeiro Junior, A. J. Fernandes Junior, and F. Prezoto. 2010. Uso da vespa social Polistes versicolor no controle de desfolhadores de eucalipto. Pesqui. Agropecu. Bras. 45: 958-964.

Engelkes, T., and N. J. Mills. 2011. A conceptual framework for understanding arthropod predator and parasitoid invasions. BioControl. 56: 383-393.

Fessl, B., G. E. Heimpel, and C. E. Causton. 2018. Invasion of an avian nest parasite, Philornis downsi, to the Galapagos Islands: colonization history, adaptations to novel ecosystems, and conservation challenges, pp. 213-266. In P. G. Parker (ed.), Disease ecology. Social and ecological interactions in the Galapagos Islands. Springer, Cham, Switzerland.

Gillespie, R. G., and G. K. Roderick. 2014. Evolution: geology and climate drive diversification. Nature. 509: 297-298.

Gosliner, T. M. 2009. Galápagos Islands, biology, pp. 357-367. In R. G. Gillespie and D. A. Clague (eds.), Encyclopedia of islands. University of California Press, Berkeley.

Grant, P. R. 1986. Ecology and evolution of Darwin's finches. Princeton University Press, Princeton, NJ.

Grant, P. R., and B. R. Grant. 1997. The rarest of Darwin's finches. Conserv. Biol. 11: 119-126.

Heraty, J., and S. Abedrabbo. 1992. Galápagos and the Polistes menace. Sphecos. 23: 11-12.

Hervías-Parejo, S., and A. Traveset. 2018. Pollination effectiveness of opportunistic Galápagos birds compared to that of insects: from fruit set to seedling emergence. Am. J. Bot. 105: 1142-1153.

Keane, R. M., and M. J. Crawley. 2002. Exotic plant invasions and the enemy release hypothesis. Trends Ecol. Evol. 17: 164-170.

Köhler, A. 2008. Floral preferences of the polistine wasp Polistes versicolor versicolor Olivier, 1792 (Hymenoptera: Vespidae: Polistinae, Polistini) in Santa Cruz do Sul, Southern Brazil. Biociências 16: 162-165.

Kudô, K., K. Komatsu, K. Konishi, S. Mateus, R. Zucchi, and F. S. Nascimento. 2013. Bionomic notes on Pachysomoides sp. (Hymenoptera: Ichneumonidae), a parasitoid of the Neotropical social wasp Polistes satan Bequaert (Hymenoptera: Vespidae). Entomol. Sci.16: 360-362.

Lack, D. 1947. Darwin's finches. Cambridge University Press, Cambridge, United Kingdom.

Landry, B., D. Adamski, P. Schmitz, C. E. Parent, and L. Roque-Albelo. 2006. Taygete sphecophila (Meyrick) (Lepidoptera; Autostichidae): redescription of the adult, description of the larva and pupa, and impact on Polistes wasps (Hymenoptera; Vespidae) nests in the Galapagos Islands. Rev. Suisse Zool. 113: 307-323.

Lasso-Vaca, M. T. 1997. Ecología e impacto de la avispa introducida (Polistes versicolor, Vespidae-Hymenoptera) en las islas Floreana y Santa Cruz. Galápagos, Ecuador. Thesis. Pontificia Universidad Católica de Ecuador, Quito, Ecuador.

McMullen, C. K. 1999. Flowering plants of the Galápagos. Cornell University Press, Ithaca.

Mollá, O., B. Shrestha, C. Sevilla, D. Rueda, F. Rivas, and H. W. Herrera. 2020. First record of Hirsutella saussurei in the Galápagos Islands and first evidence parasitizing the invasive paper wasp, Polistes versicolor. Rev. Bras. Entomol. 64: e20200031.
Montalva, C., E. Rojas, E. Valenzuela, and R. A. Humber. 2017. Hirsutella sp. (Hypocreales: Ophiocordycipitaceae) affecting the invasive social wasp Vespula vulgaris (Hymenoptera: Vespidae) in southern Chile. Fla. Entomol. 100: 663-666.

de Oliveira, S. A., M. M. de Castro, and F. Prezoto. 2010. Foundation pattern, productivity and colony success of the paper wasp, Polistes versicolor. J. Insect Sci. 10: 125. insectscience.org/10.125.

Parent, C. E., A. Caccone, and K. Petren. 2008. Colonization and diversification of Galápagos terrestrial fauna: a phylogenetic and biogeographical synthesis. Philos. Trans. R. Soc. Lond. B. Biol. Sci. 363: 3347-3361.

Peck, S. B. 2006. Beetles of the Galápagos Islands, Ecuador: evolution, ecology, and diversity (Insecta: Coleoptera). NRC Research Press, Canada.

Peck, S. B., J. Heraty, B. Landry, and B. J. Sinclair. 1998. Introduced insect fauna of an oceanic archipelago: the Galápagos Islands, Ecuador. Am. Entomol. 44: 218-236.

Prezoto, F., H. H. Santos-Prezoto, V. L. Machado, and J. C. Zanuncio. 2006. Prey captured and used in Polistes versicolor (Olivier) (Hymenoptera: Vespidae) nourishment. Neotrop. Entomol. 35: 707-709.

Prezoto, F., C. Ribeiro Júnior, S. A. O. Cortes, and T. Elisei. 2007. Manejo de vespas e marimbondos em ambiente urbano, pp. 123-126. In A. S. Pinto, M. M. Rossi, and E. Salmeron (eds.), Manejo de Pragas Urbanas. CP2, Piracicaba, Brazil.

Prezoto, F., M. M. de Castro, A. R. de Souza, and N. Gobbi. 2015. Foundress association in the paper wasp Polistes simillimus (Hymenoptera: Vespidae). Fla. Entomol. 98: 556-559.

Prezoto, F., T. T. Maciel, M. Detoni, A. Z. Mayorquin, and B. C. Barbosa. 2019. Pest control potential of social wasps in small farms and urban gardens. Insects. 10: 192.

Ramos, F. A., and I. R. Diniz. 1993. Seasonal cycles, survivorship and growth of colonies of Polistes versicolor (Hymenoptera, Vespidae) in the urban area of Brasília, Brazil. Entomologist. 112: 191-200.

Raveret Richter, M. 2000. Social wasp (Hymenoptera: Vespidae) foraging behavior. Ann. Rev. Entomol. 45: 121-150.

Reed, H. C., and S. B. Vinson. 1979. Nesting ecology of paper wasps (Polistes) in a Texas urban area (Hymenoptera: Vespidae). J. Kansas Entomol. Soc. 52: 673-689.

Richards, O. W. 1978. The social wasps of America excluding the Vespinae. British Museum of Natural History, London, United Kingdom.

Roque-Albelo, L. 2006. Diversity and ecology of the Lepidoptera in the Galápagos Islands, Ecuador. Ph.D. dissertation, Cardiff University, United Kingdom.

Roque-Albelo, L., and C. Causton. 1999. El Niño and introduced insects in the Galapagos Islands: different dispersal strategies, similar effects. Noticias de Galápagos. 60: 30-36.

Roque-Albelo, L., and B. Landry. 2018. CDF checklist of Galapagos butterflies and moths. In F. Bungartz, H. Herrera, P. Jaramillo, N. Tirado, G. JiménezUzcátegui, D. Ruiz, A. Guézou, and F. Ziemmeck (eds.). Charles Darwin Foundation Galapagos Species Checklist. Charles Darwin Foundation, Puerto Ayora, Galapagos. http://darwinfoundation.org/datazone/ checklists/terrestrial-invertebrates/lepidoptera/

Simberloff, D. 2000. Extinction-proneness of island species-causes and management implications. Raffles B. Zool. 48: 1-9.

Somavilla, A., K. Schoeninger, A. F. Carvalho, R. S. Menezes, M. A. Del Lama, M. A. Costa, and M. L. Oliveira. 2015. Record of parasitoids in nests of social wasps (Hymenoptera: Vespidae: Polistinae). Sociobiology. 62: 92-98.

Somavilla, A., B. C. Barboza, F. Prezoto, and M. L. Oliveira. 2020. Infection and behavior manipulation of social wasps (Vespidae: Polistinae) by Ophiocordyceps humbertii in Neotropical forests: new records of wasp-zombification by a fungus. Stud. Neotrop. Fauna E. 55: 23-28.

de Souza Tavares, W., A. M. Dias, M. M. de Souza, R. Silva-Filho, J. E. Serrão, and J. C. Zanuncio. 2013. Pachysomoides sp. (Hymenoptera: Ichneumonidae: Cryptinae) parasitizing Polistes versicolor (Hymenoptera: Vespidae) in Viçosa, Minas Gerais State, Brazil. Entomol. Am. 119: 80-84.

Toral-Granda, M. V., C. E. Causton, H. Jäger, M. Trueman, J. C. Izurieta, E. Araujo, M. Cruz, K. K. Zander, A. Izurieta, and S. T. Garnett. 2017. Alien species pathways to the Galapagos Islands, Ecuador. Plos One. 12: e0184379.

Traveset, A., R. Heleno, S. Chamorro, P. Vargas, C. K. McMullen, R. CastroUrgal, M. Nogales, H. W. Herrera, and J. M. Olesen. 2013. Invaders of 
pollination networks in the Galápagos Islands: emergence of novel communities. Proc. Royal Soc. B. 280: 20123040.

Trueman, M., and N. d'Ozouville. 2010. Characterizing the Galapagos terrestrial climate in the face of global climate change. Galapagos Res. 67: 26-37.

Tye, A., and J. Francisco-Ortega. 2011. Origins and evolution of Galápagos endemic vascular plants, pp. 89-153. In D. Bramwell and J. Caujapé-Castells (eds.), The biology of Island Floras. Cambridge University Press, Cambridge.

Whittaker, R. J., and J. M. Fernández-Palacios. 2007. Island biogeography. Oxford University Press, Oxford, United Kingdom.

Wiggins, I. L., and D. M. Porter. 1971. Flora of the Galápagos islands. Stanford University Press, Stanford. 